\title{
STRATEGI KOMUNIKASI PEMASARAN KOPI MELALUI DIGITALPRENEUR STUDI KASUS PADA CV. PUTRI CAHAYA CEMERLANG (KOPI ONCAK)
}

\author{
${ }^{1)}$ Filda Angellia ${ }^{2)}$ Mayang Riyantie \\ Email: ${ }^{1)}$ angellia_filda@yahoo.co.id ${ }^{2)}$ namanya.mayang@gmail.com \\ ${ }^{1)}$ Program Studi Sistem Informasi, Fakultas Ilmu Komputer \\ ${ }^{2)}$ Program Studi Komunikasi, Fakultas Ilmu Sosial Dan Ilmu Politik \\ ${ }^{1)}{ }^{2)}$ Institut Bisnis dan Informatika (IBI) Kosgoro 1957
}

\begin{abstract}
ABSTRAK
Area DKI Jakarta adalah area yang mempunyai potensi bisnis yang cukup besar untuk berkembang karena area tersebut merupakan area padat penduduk dan padat akan kegiatan bisnis serta perekonomian lainnya. Pertambahan jumlah penduduk juga terus meningkat sehingga kebutuhan akan bahan atau barang tertentu juga cenderung ikut meningkat. Seiring dengan era Industrial 4.0 yang mengusung tema IoT (Internet of Things), maka sangat diperlukan penentuan strategi komunikasi yang sesuai. Pemasaran berbasis digital merupakan salah satu strategi yang cukup vital dan sangat dominan untuk meningkatkan jumlah pangsa pasar (konsumen).Begitu pun dengan usaha penjualan kopi, dimana kopi sudah menjadi kebutuhan sehari-hari yang harus terpenuhi. Kopi telah dianggap memiliki pangsa pasar besar dalam industri. Sehingga untuk proses produksi dan penjualannya butuh strategi untuk ditingkatkan atau minimal bertahan di pasaran. Penelitian ini tergolong penelitian kualitatif. Data yang diperlukan diperoleh dengan studi lapangan, dokumentasi survei lapangan, dan hasil wawancara. Hasil observasi dan survei lapangan memperlihatkan data bahwa usaha penjualan bahan kebutuhan sehari-hari seperti kopi menggunakan strategi pemasaran berbasis digital (digital marketing) yang terus dilakukan bersamaan dengan strategi pemasaran lain.
\end{abstract}

Kata Kunci: Komunikasi Pemasaran, Digital Marketing, Pemasaran, Penjualan Kopi, Digital Preneur

\section{PENDAHULUAN}

Wilayah DKI Jakarta yang terus tumbuh dan berkembang dalam fase kependudukan baik dari segi kuantitas maupun kualitas. Wilayah DKI Jakarta dengan jumlah 44 kecamatan dan 267 kelurahan dengan luas sekitar 664,01 km² (lautan: 6.977,5 km²) dihuni sekitar 10.557.810 jiwa (2019) Pertumbuhan penduduk ini didukung dengan adanya laju perpindahan penduduk dari daerah lain ke wilayah Jakarta dengan berbagai faktor pendorong perpindahan penduduk tersebut misalnya, mencari penghidupan, menjalankan aktivitas perekonomian seperti berdagang, dan lain-lain. DKI Jakarta sebagai pusat berjalannya aktivitas perekonomian terbesar melingkupi beberapa sektor industri dan bisnis antara lain : industri pangan, industri kebutuhan seharihari (teh, gula, kopi, garam) dan banyak industri lainnya.

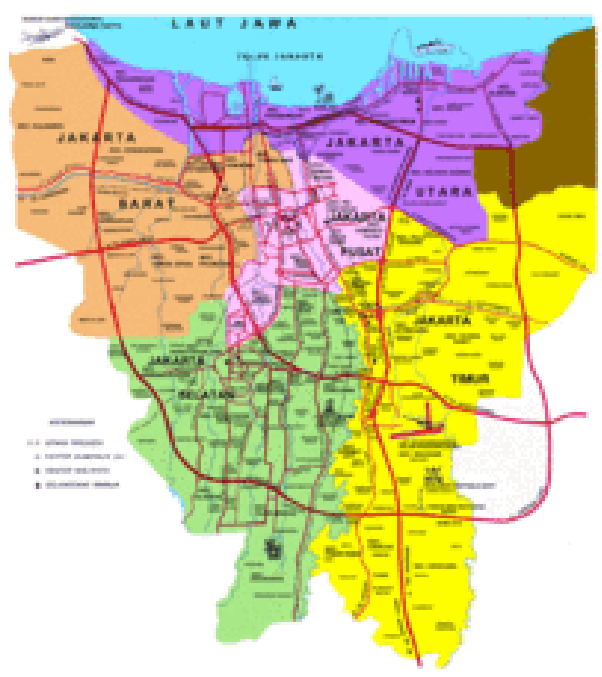

Gambar 1. Peta Wilayah DKI Jakarta 
Untuk mendukung data kependudukan berikut disajikan kembali data populasi penduduk DKI Jakarta dalam tabel berikut ini :

Tabel 1. Populasi Kepadatan Penduduk DKI Jakarta

\begin{tabular}{|c|c|c|c|c|c|c|}
\hline \multirow{2}{*}{ Krbupatony Kot } & \multicolumn{2}{|c|}{ Pendudut } & \multicolumn{2}{|c|}{ Laju Pertumbuhan } & \multicolumn{2}{|c|}{ Eqpadatan } \\
\hline & 2016 & 2017 & 2016 & 2017 & 2015 & 2017 \\
\hline Kepulauan Seribu & 23,616 & 23,897 & 1.18 & 1.19 & 2,714 & 2,747 \\
\hline Jabarta Selatan & $2,206,732$ & $2,226,830$ & 0.96 & 0.91 & 15,621 & 15,763 \\
\hline Jakarta Timur & $2,060,910$ & $2,892,709$ & 0.8 & 0.83 & 15,298 & 15,395 \\
\hline Jakartu Pusut & 917,754 & 921,344 & 0.39 & 0.39 & 19,068 & 19,143 \\
\hline Jakarta Barat & $2,496,002$ & $2,528,065$ & 132 & 1.28 & 19,268 & 19.516 \\
\hline Jakarta Utara & $1,764,614$ & $1,781,316$ & 0.99 & 0.95 & 12,092 & 12,146 \\
\hline
\end{tabular}

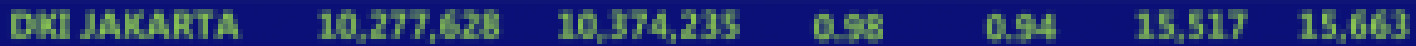

Sumber: Laporan Tahunan Puskesmas Kecamatan Jagakarsa 2018

Secara Geografis, Wilayah DKI Jakarta merupakan kota yang masuk dalam kategori kota aktif industri ataupun perdagangan serta aktivitas perekonomian. Aktivitas industri dan perdagangan masuk dalam taraf perkembangan yang sangat pesat ditemukan di wilayah ini. DKI Jakarta adalah daerah yang cukup potensial dan juga strategis untuk aktivitas investasi dengan berbagai jenis usaha dan bisnis hal tersebut dikarenakan antara lain akses menuju wilayah lainnya yang cenderung sangat mudah, serta memiliki Sumber Daya Manusia (SDM) yang terampil dan profesional, dengan banyaknya kalangan terdidik di wilayah DKI Jakarta.

Pergolakan bidang ekonomi di DKI Jakarta semakin berkembang dengan berkembangnya populasi penduduk yang juga meningkatkan angka kebutuhan harian penduduk. Hal ini adalah peluang yang sangat besar bagi pebisnis, salah satunya adalah bisnis produksi dan penjualan kopi. Bisnis produksi dan penjualan kopi ini adalah bentuk usaha dalam bidang industri dan perdagangan untuk memenuhi kebutuhan harian. Bisnis produksi dan penjualan kopi ini cenderung 'menjamur' di DKI Jakarta mengingat bahwa kopi adalah kebutuhan harian yang banyak dicari dan diminati masyarakat DKI Jakarta khususnya untuk dinikmati di berbagai kesempatan. Pada umumnya usaha perdagangan kopi yang kini hadir adalah kopi siap minum dengan cita rasa unik yang ditawarkan beberapa industri minuman berbahan dasar kopi. Namun, para pecinta kopi juga banyak yang mencari sensasi rasa dan cara menikmati kopi tersebut, sehingga tak urung juga ikut berkembang industri kopi murni yang siap diolah dengan berbagai cara unik dan penuh sensasi.

Usaha produksi dan penjualan kopi di wilayah DKI Jakarta ini merupakan bisnis atau usaha yang secara kompetitif bermunculan dengan berbagai penawaran sensasi rasa kopi. Jenis yang ditawarkan antara lain adalah biji kopi murni, bubuk kopi murni, kopi campuran, kopi olahan, hingga kopi siap minum. 


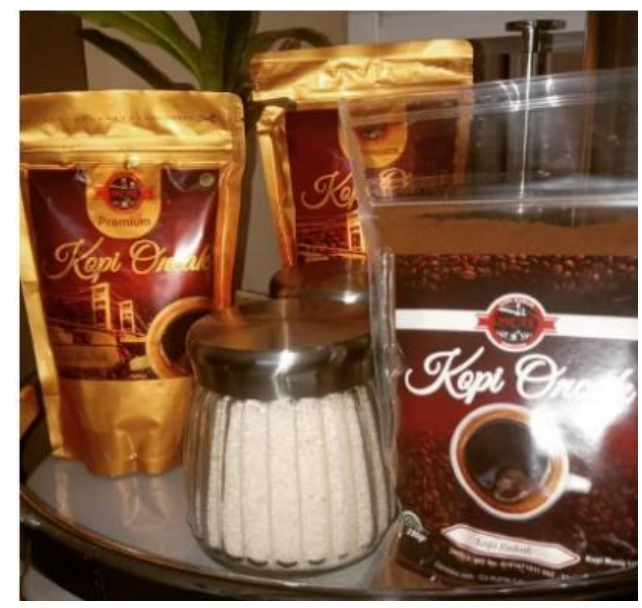

Gambar 2. Jenis Kopi Oncak

Sumber: Owner Kopi Oncak

Pelaku bisnis industri kopi ini membidik pasar para pencinta kopi dari berbagai kalangan dan usia karena melihat peluang kebutuhan harian kopi yang kian meningkat dari hari ke hari. Pada dasarnya, target segmentasi pasar konsumen kopi adalah masyarakat umum, namun lebih detailnya adalah pada range usia antara 18- 60 tahun. Pada interval usia tersebut, kopi oncak memiliki peluang yang besar untuk menargetkan pada keanekaragaman konsumen, maka penyediaan produksi kopi dengan unik dan nikmat berikut cara minum kopi pun disesuaikan dengan selera masyarakat.

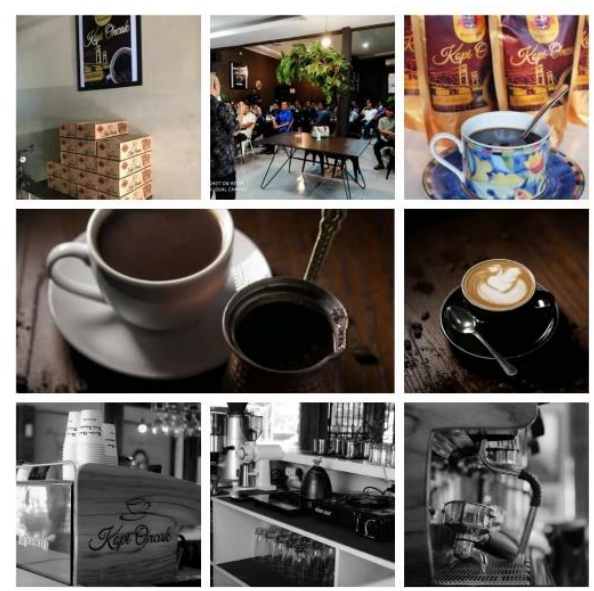

Gambar 3. Pengolahan Kopi

Sumber: Facebook Kopi Oncak

Berdasarkan jenis dan berbagai cara menikmati kopi, khususnya kopi oncak yang ditawarkan dalam berbagai bentuk rasa dan kemasan serta ukuran mulai dari harga Rp. 3.500,-/kemasan sampai dengan Rp. 250.000,-/kemasan, menyesuaikan dengan cita rasa penyajian dan ukuran kopi oncak itu sendiri . Secara kompetitif usaha produksi dan penjualan kopi oncak ini dipengaruhi selain oleh rasa kopi dan penyajiannya tapi juga kepada bagaimana metode dan strategi pemasarannya.

Secara umum, manajemen pemasaran usaha produksi dan penjualan kopi oncak dapat dikatakan sudah optimal. Namun target pemasaran belum tentu dapat dicapai dengan strategi pemasaran yang tidak tepat sasaran. Pada strategi pemasaran yang sangat penting harus dilakukan oleh pelaku usaha maupun bisnis baik di bidang penyedia/penjualan barang atau jasa. Strategi pemasaran perlu dilakukan karena setiap produk baik barang maupun jasa memerlukan metode dan strategi yang tepat untuk "mengantarkan" value produk barang atau jasa tersebut. 
Pemasaran menurut American Marketing Association adalah proses perencanaan dan pelaksanaan rencana dalam hal penetapan harga, promosi, dan distribusi ide-ide, barang- barang dan jasa untuk menciptakan pertukaran yang memuaskan tujuan-tujuan individual dan organisasi.

Sedangkan strategi pemasaran menurut Kotler (2008:58) beranggapan bahwa unit bisnis akan tercapai tujuannya jika perusahaan memaksimalkan logika pemasaran pada pelaksaannya. Menurut Radiosunu (2001:27), ada lima konsep strategi pemasaran, diantaranya sebagai berikut:

1) Segmentasi Pasar

Pada dasarnya pasar akan selalu terdiri dari bermacam-macam karakteristik pembeli dengan kebutuhan yang berbeda satu sama lainnya. Sehingga dengan demikian, perusahaan tak mungkin dapat memenuhi kebutuhan semua pembeli. Oleh karenanya, sifat pasar yang heterogen tersebut harus dikelompokkelompokan oleh perusahaan ke dalam satuan pasar yang bersifat homogen.

2) Market Positioning

Selain untuk memenuhi segmentasi pasar secara keseluruhan, strategi pemasaran yang kedua adalah perusahaan harus dapat memilih pola spesifik pemusatan pasar mana yang akan maksimal memberikan kesempatan untuk mendapatkan kedudukan yang kuat. Singkatnya, untuk mendapatkan laba yang maksimal, perusahaan perlu merumuskan segmen pasar yang tepat.

3) Targeting

Targeting adalah strategi memasuki segmen pasar yang dijadikan sasaran penjualan.

4) Strategi Mix Pemasaran

Dalam mempengaruhi terdapat variabel-variabel yang dapat mempengaruhi tanggapan konsumen, yakni: Product, Place, Promotion dan Price (4P).

5) Timing Strategy

Konsep pemasaran yang terakhir adalah menentukan kapan strategi tersebut diaplikasikan. Sehingga kita dapat melihat adanya kesempatan baik sebelum mempersiapkan produksi.

Menyikapi peluang usaha kopi di DKI Jakarta cukup besar, maka perlu disikapi bahwa untuk 'menjaring' konsumen, harus dilakukan strategi pemasaran yang sesuai dan tepat pada sasaran. Mengingat semakin banyaknya usaha bidang perkopian bermunculan di DKI Jakarta yang menawarkan berbagai tawaran yang beragam dan menarik membuat tingkat persaingan usaha/bisnis menjadi sangat kompetitif. Saat ini di era Industrial 4.0 yang mengusung tema IoT (Internet of Things) atau basis digital, maka hal ini memerlukan penerapan strategi pemasaran berbasis digital atau biasa disebut digitalpreneur yang akan dapat mencapai target yang direncanakan. Merujuk pada data tersebut maka penelitian kualitatif ini dilakukan untuk mengetahui sejauh mana digitalpreneur sebagai strategi pemasaran yang diterapkan oleh pelaku usaha produksi dan penjualan kopi dapat 'menjaring' lebih banyak jumlah konsumen.

\section{METODE PENELITIAN}

Peneliti dalam melakukan penelitian ini menggunakan metode deskriptif kualitatif berdasarkan pertimbangan bahwa penelitian kualitatif digunakan demi menghasilkan jawaban untuk pertanyaan riset sehingga dapat diketahui bagaimana penerapan digitalpreneur sebagai strategi pemasaran yang diterapkan oleh pelaku usaha produksi dan penjualan kopi dapat 'menjaring' lebih banyak jumlah konsumen.

Metode deskriptif kualitatif adalah suatu penelitian yang menghasilkan data yang bersifat deskriptif (penggambaran) berupa fakta-fakta yang tertulis maupun lisan dari perilaku yang dicermati, dalam keadaan yang berlangsung secara wajar dan ilmiah dan bukan dalam kondisi yang terkendali (Sanafiah, 2005:18). Maka metode ini mampu mendeskripsikan elemen-elemen yang ada dalam strategi pemasaran pada usaha produksi dan penjualan kopi secara mendalam. 
Data yang digunakan pada penelitian ini berasal dari hasil survei/studi lapangan, wawancara langsung, dan proses pengumpulan data dan informasi berupa dokumen yang terkait. Data tersebut diolah berdasarkan analisis, pemilihan dan pengelompokan data agar mendapatkan hal-hal yang tepat untuk menjabarkan masalah dan solusinya sesuai dengan apa yang ingin dicapai pada tujuan penelitian.

Validitas dapat dilakukan salah satunya menggunakan teknik triangulasi data. Triangulasi data dirasa perlu untuk mengurangi tingkat subjektifitas dalam penelitian kualitatif, sehingga teknik triangulasi data dilakukan dengan cara me-rechek temuan yang ada di lapangan oleh peneliti dengan beberapa cara, seperti triangulasi dengan sumber, metode atau dengan teori (Moleong, 2004:332).

\section{HASIL DAN PEMBAHASAN}

\subsection{Pemetaan Strategi Pemasaran Kopi Oncak}

Kegiatan utama yang harus dilakukan oleh pengusaha guna meningkatkan jumlah penjualan adalah melalui strategi pemasaran. Pemasaran yang baik akan selalu menitikberatkan kepada loyalitas dan kepuasan pelanggan yang pada akhirnya akan mendatangkan keuntungan jangka panjang. Begitu pun yang dilakukan oleh Kopi Oncak yang tengah berupaya keras dalam melakukan strategi pemasarannya. Komunikasi Pemasaran Kopi Oncak saat ini adalah mengandalkan komunikasi manual dengan menggunakan metode Word of Mouth (WoM). Komunikasi pemasaran sangat berhubungan erat dengan karakter dan perilaku masyarakat secara luas. Sebagian besar lingkungan masyarakat memiliki kebutuhan dan tren yang berbeda-beda (Patrick dalam Suwatno, 2017:57). Aktivitas utama dari komunikasi dalam pemasaran adalah melakukan analisis dan identifikasi kelompok pasar yang beragam. Proses tersebut dilakukan dengan cara melakukan pemetaan strategis yaitu Segmenting, Targeting, dan Positioning (STP).

\subsection{Segmentation Kopi Oncak}

Pembagian konsumen yang berbeda-beda berdasarkan profil segmen dinamakan segmentasi pasar. Banyak cara yang dapat dilakukan dalam memilah dan memilih konsumen berdasarkan kategori, namun Suwanto mengatakan segmentasi pasar yang paling banyak dikategorikan adalah berdasarkan demografi, psikografi, geografi dan behavioral (Suwanto, 2017:60)

Berdasarkan segmentasi pasar dalam kasus ini dianalisis bahwa segmentasi pasar yang dilakukan oleh Kopi Oncak berdasar pada segmentasi demografi. Segmentasi demografi tersebut berdasarkan pada kualifikasi jenis kelamin, usia, faktor ekonomi (penghasilan per bulan), dan jenjang pendidikan.

Jika didetailkan kembali, implementasi segmentasi pasar Kopi Oncak yaitu pada target usia antara 2633 tahun. Jika dilihat dari kategori jenis kelamin, Kopi Oncak memiliki target dengan jenis kelamin laki-laki dengan angka yang relatif dominan. Untuk pecinta dan penikmat kopi memang masih banyak diminati oleh gender laki-laki dengan berbagai sensasi cara 'ngopi' di berbagai kesempatan

Sedangkan dari faktor ekonomi (pendapatan per bulan), Kopi Oncak adalah kelas masyarakat dengan tingkat ekonomi menengah kebawah karena dilihat dari jumlah penghasilan per bulannya adalah di pertengahan range ke arah bawah. Hal tersebut dapat dilihat dari harga kopi oncak yang relatif murah jika dibanding dengan kopi sejenis lainnya dengan kualitas rasa yang cukup baik.

Dilihat dari jenjang pendidikan, Kopi Oncak memiliki konsumen berlatar belakang pendidikan SMA sederajat dan mahasiswa serta banyaknya kalangan muda yang kini 'menggandrungi' berbagai jenis kopi. 


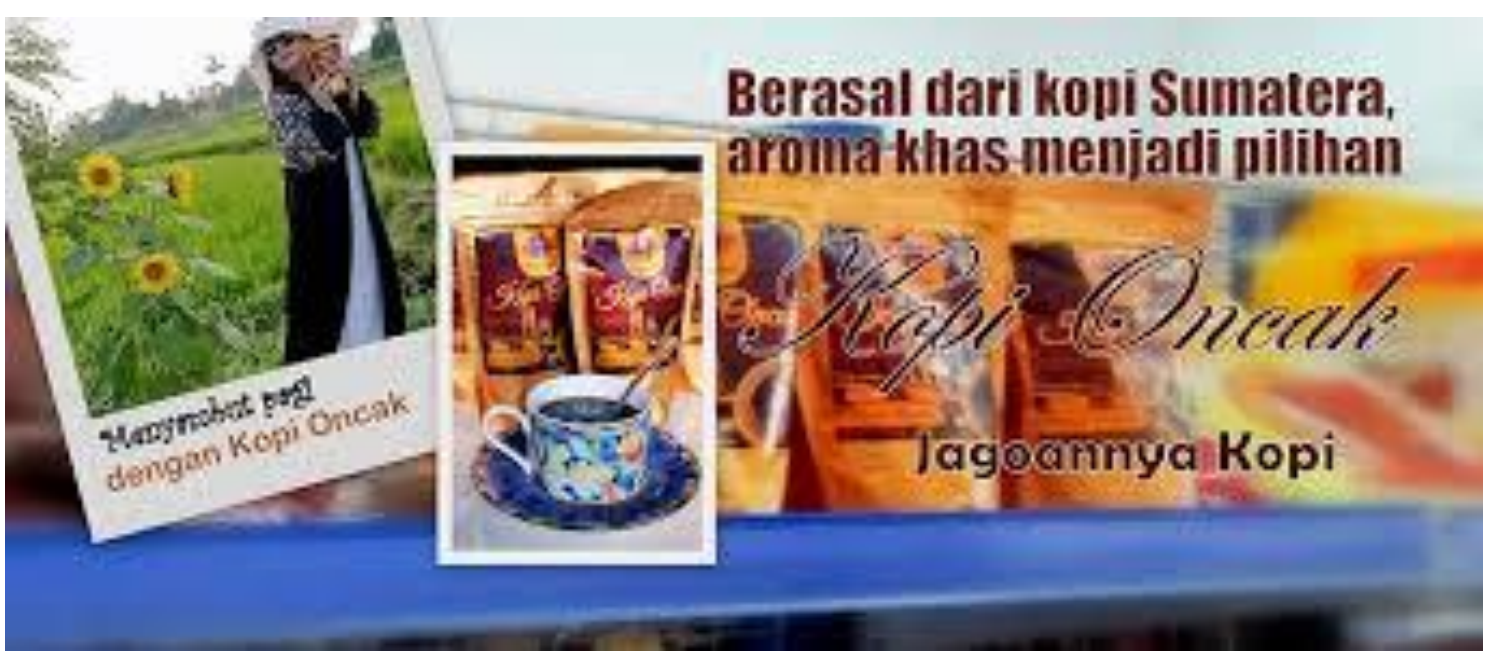

Gambar 4. Tag Line Kopi Oncak

Sumber: Facebook Kopi Oncak, 2020
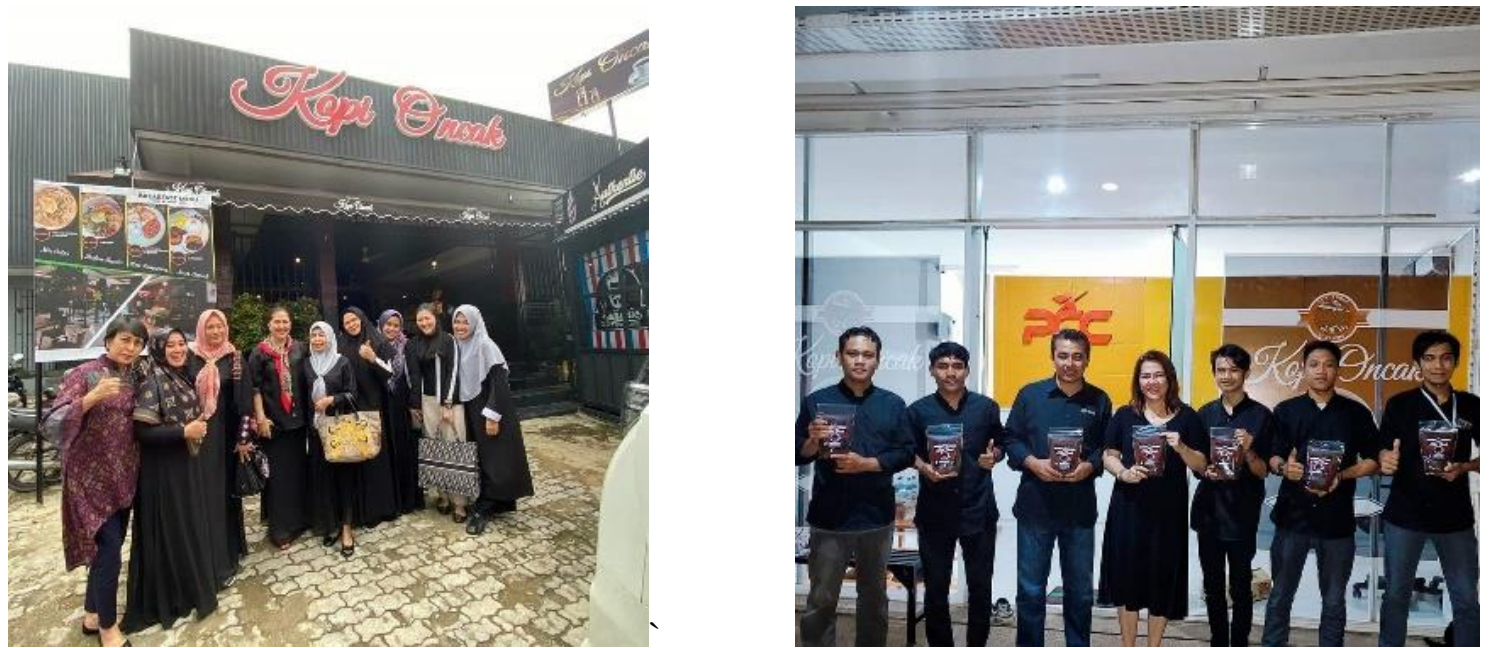

Gambar 5. Cafe dan Gudang Kopi Oncak

Sumber: Facebook Kopi Oncak, 2020
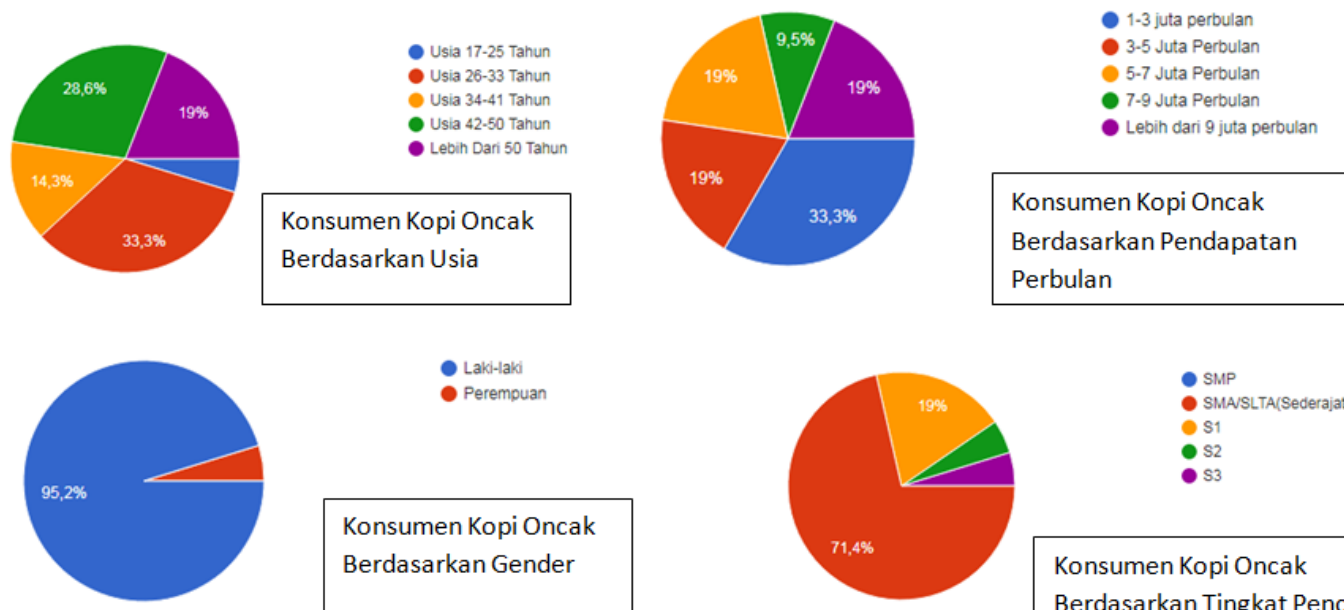

- Laki-laki

Konsumen Kopi Oncak Berdasarkan Gender

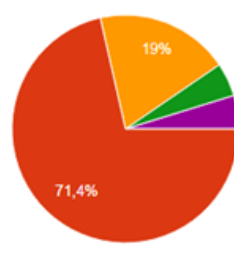

- SMP

- SMANLLTA(Sederaiar)

s1

$\$ 2$

Konsumen Kopi Oncak

Berdasarkan Tingkat Pendidikan

Gambar 6. Segmentation Kopi Oncak

Sumber: Diolah oleh Penulis 


\section{3. $\quad$ Targeting Kopi Oncak}

Sejak awal sebelum program pemasaran diimplementasikan hendaknya seorang marketer merumuskan dahulu mengenai strategi targeting. Karena merupakan salah satu indikator keberhasilan dalam melakukan bisnis. Kemampuan seorang marketer akan diuji ketika harus menganalisis siapa yang nanti akan menjadi target pemasarannya. Seperti yang dikatakan Suwatno, bahwa targeting harusnya secara gamblang juga tegas ditentukan di sesi awal pemasaran (Suwatno, 2017:66).

Menurut Patrick De Pelsmacker (2013:67), ada beberapa tipe dasar dari strategi targeting, antara lain: Concentration on one segment, Selective specialization, Product specialization, Market specialization, dan Full market coverage

Kopi Oncak merupakan bisnis yang termasuk pada kategori produk specialization. Pada kategori ini Kopi Oncak berkonsentrasi kepada Product Specialization maksudnya

Kopi Oncak dirasa perlu untuk berkomitmen dalam membuat produk khusus dan unik dibandingkan produk lainnya, dalam hal ini kekhasan dari kopi oncak yang merupakan jenis kopi murni. Dengan cara yang demikian, perusahaan dapat membangun citra yang kuat pada produk yang lebih spesifik. Karena dalam menentukan targeting seorang marketer tidak bisa dilakukan sembarangan, maka diperlukan teknis dan proses melalui pendekatan outside-in. Artinya pendekatan tersebut harus berbasis pada data dan fakta real yang diperoleh di lapangan. Mengapa pendekatan outside-in lebih penting dibandingkan inside-out, karena insideout lebih mengedepankan analisis logika tanpa referensi yang menunjang lapangan sehingga ketepatan dan akurasinya masih diragukan (Suwatno, 2017:68).
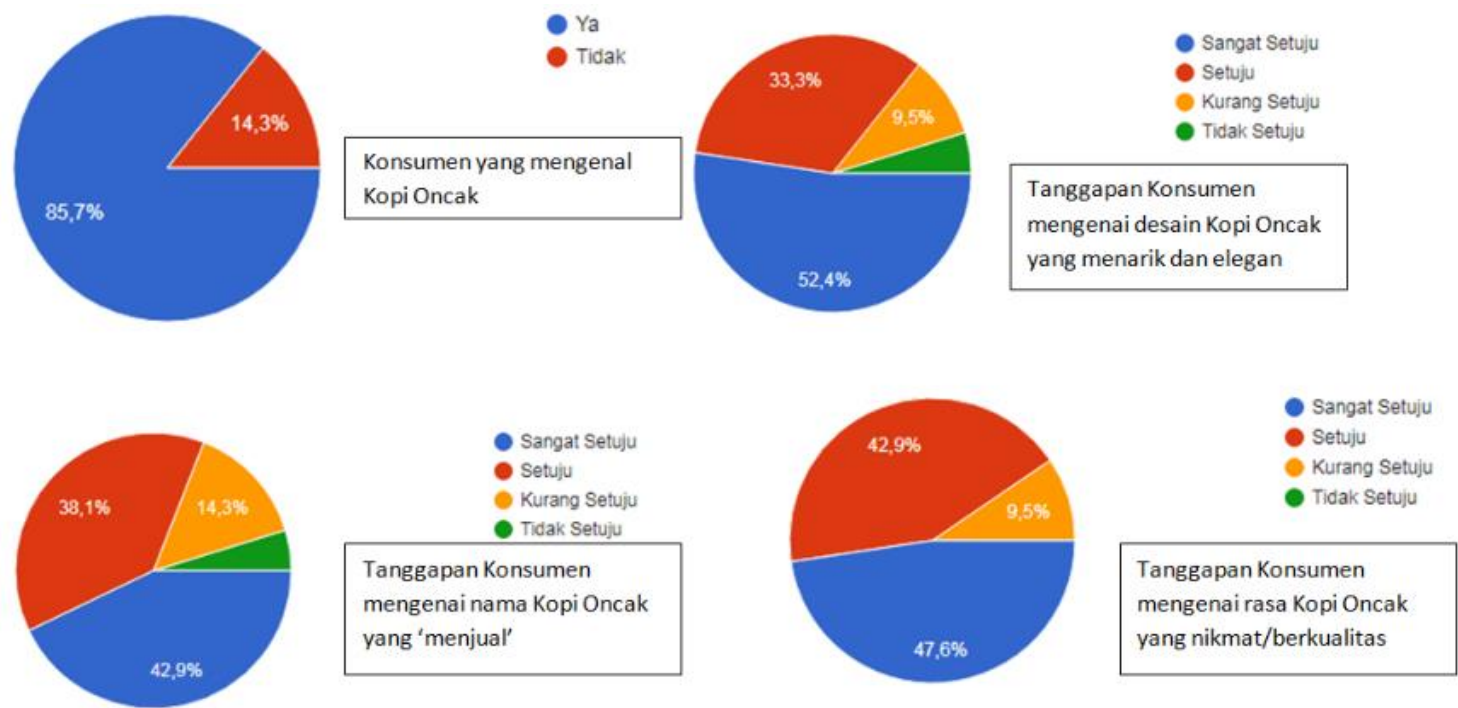

Gambar 7. Targeting Kopi Oncak (1)

Sumber: Diolah oleh Penulis 


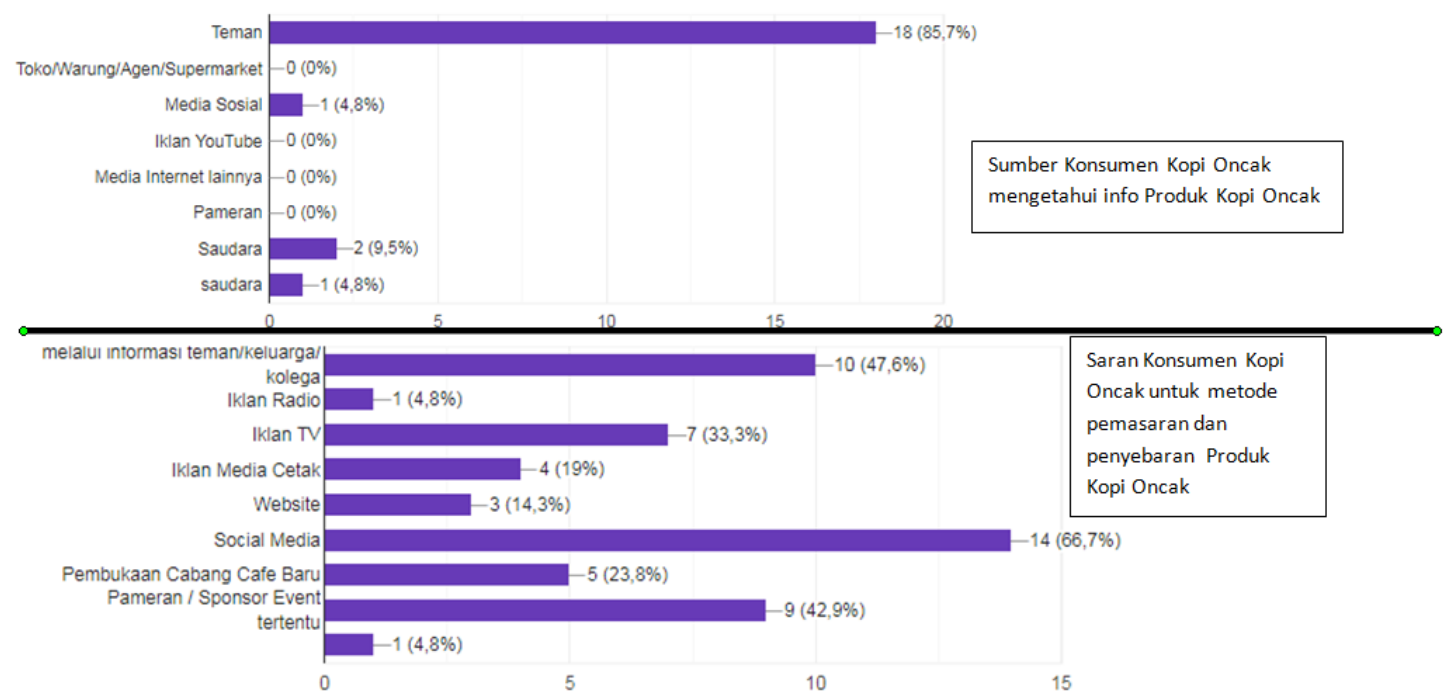

Gambar 8. Targeting Kopi Oncak (2)

Sumber: Diolah oleh Penulis

\subsection{Positioning Kopi Oncak}

Strategi positioning juga teramat penting karena hal tersebut yang menentukan posisi brand suatu produk di antara brand lainnya. Hal ini memiliki fungsi untuk membedakan suatu produk dengan produk lain di dalam persepsi konsumen. Saat ini kopi oncak memiliki pesaing yang perlu dipertimbangkan keberadaannya, seperti kopi torabica dan caffino yang baru-baru ini di rilis oleh PT. Sumber Kopi Prima. Dalam pasar sebuah persaingan dalam bisnis tak dapat dihindari maka kita harus membekali diri kita dengan beberapa ilmu dan pengalaman pemasaran agar usaha kita tidak lekang digerus oleh persaingan bisnis.

Dengan ancaman yang muncul dari pesaing sejenis, maka Kopi Oncak dirasa perlu melakukan positoning yang lebih jelas agar konsumen dapat memberikan posisi brand kopi oncak terhadap pesaing lainnya. Saat ini Kopi Oncak lebih menonjolkan keunikannya melalui kopi bubuk hitam murni dengan cita rasa khas kopi Sumatera. Berbeda dengan kopi lainnya yang masih bercampur dengan bahan pendukung lainnya dalam bubuk kopi.

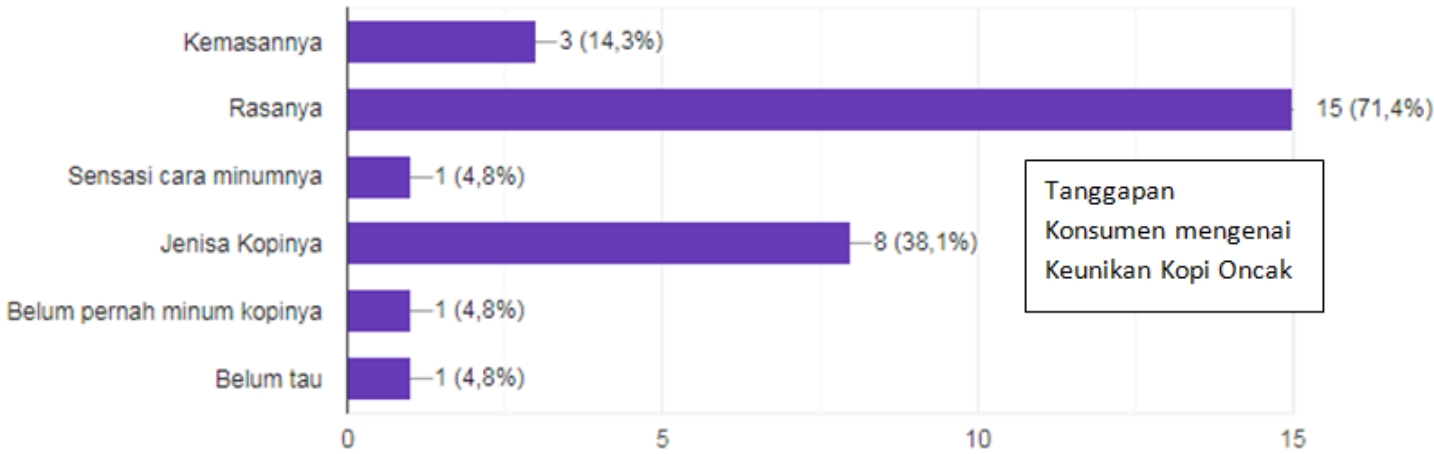

Gambar 9. Positioning Kopi Oncak (2)

Sumber : Diolah oleh Penulis

\subsection{Digitalpreneur Kopi Oncak}

Bisnis digital mulai harus dilakukan saat ini mengingat setiap konsumen mengandalkan kemudahan dan kecepatan dalam proses pembelian. Saat ini iklan dalam bentuk digital, penggunaan smartphone untuk melakukan transaksi bisnis meningkat, peningkatan infrastruktur telekomunikasi pendukung bisnis juga meningkat. Pesatnya perkembangan teknologi digitalpreneur sangat berdampak pada pemasaran. 
Revolusi teknologi informasi telah mengubah lanskap dunia pemasaran dalam beberapa tahun terakhir ini. Metode komunikasi pemasaran yang sebelumnya bersifat tradisional dan konvensional, kini telah terintegrasi dalam dunia digital (Suwatno, 2017:99). Transaksi jual beli tidak lagi harus dilakukan dengan tatap muka, namun dapat dilakukan melalui dunia maya.

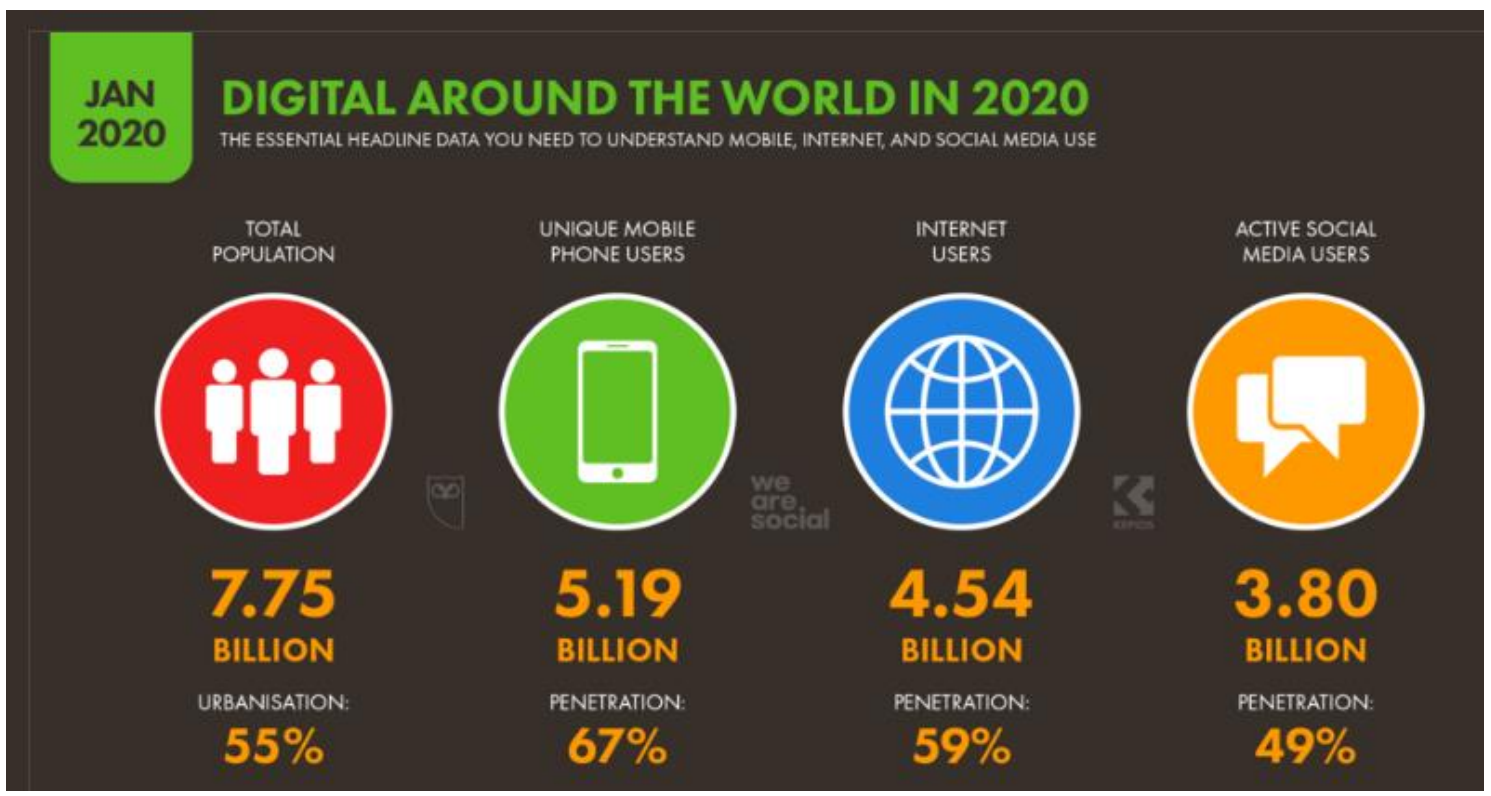

Gambar 5. Penggunaan Teknologi Digital Tahun 2020

Sumber: https://datareportal.com/reports/digital-2020-global-digital-overview

Berdasarkan data tersebut, terlihat bahwa strategi jual beli online (digital )sangat dibutuhkan untuk meningkatkan penjualan /pemasaran kopi oncak. Kecenderungan tersebut tejadi karena digitalpreneur dinilai lebih mudah dan prospektif sehingga dapat membantu pelanggan potensial dalam mendapatkan informasi mengenai produk dan dapat melakukan transaksi melalui internet.

Di satu sisi, digitalpreneur mempermudah pelaku bisnis mengontrol dan menyediakan segala kebutuhan konsumen. Konsumen juga bisa mendapatkan informasi produk hanya dengan menjelajah internet / dunia maya. Digitalpreneur dapat menjangkau konsumen kapan dan dimanapun, karena tidak terdapat batas ruang dan waktu, maka kopi oncak harus dapat mengoptimalkan pola pemasaran dengan menggunakan fasilitas tekhnologi digital yang ada. Digitalpreneur yang telah dilakukan oleh kopi oncak adalah melalui sosial media seperti, instagram, facebook, whatsapp, dan baru akan memulai dengan menggunakan website serta landing page.

Sementara itu, berdasarkan data yang dilansir oleh We are Social, sebuah agensi digital marketing di Amerika menyebutkan bahwa platform media sosial yang paling banyak digunakan di Indonesia per Januari 2017 adalah Youtube (49\%) dan Facebook (48\%). Posisi ketiga dan seterusnya ditempati oleh Instagram (39\%), Twitter (38\%), Whatsapp (38\%), dan Google (36\%). Sisanya ditempati secara berurutan oleh FB Messenger, Line, Linkedin, BBM, Pinterest, dan Wechat 


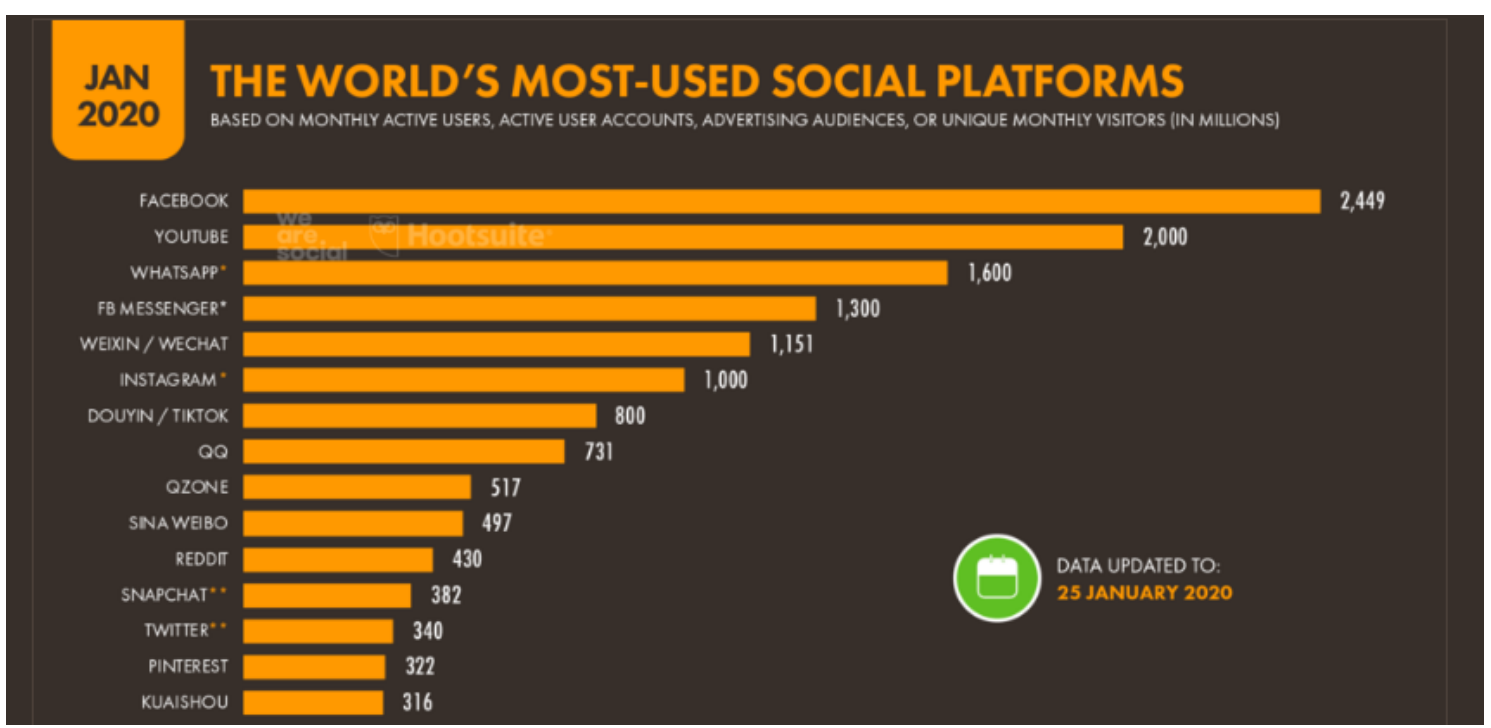

Gambar 6. Platform Media Sosial yang Paling Sering Digunakan

Sumber: https://datareportal.com/reports/digital-2020-global-digital-overview

Manajemen kopi oncak berusaha untuk memanfaatkan teknologi digitalpreneur dengan optimal. Beberapa tahun belakangan ini media sosial melalui dunia maya sangat digandrungi oleh masyarakat Indonesia, maka pihak kopi oncak pun berusaha juga turut memanfaatkan media sosial Instagram sebagai media pemasarannya. Akun Instagram kopi oncak yakni@ @opi_oncak masih belum dikelola dengan baik sehingga membutuhkan peningkatan dalam hal pengelolaan akun tersebut. Terbukti dengan masih sedikitnya jumlah followers pada akun instagram tersebut. Namun saat ini owner kopi oncak ini masih cenderung menggunakan akun pribadi owner untuk dapat melakukan pemasaran, di kemudian hari nanti akun pribadi ini harus dipisahkan dari akun pemasaran

Manajemen kopi oncak menyadari peran berbagai media sosial sebagai media digitalpreneur yang sangat membutuhkan pengelolaan yang optimal. Bukan sekedar akun yang dibuat tanpa desain dan perencanaan, namun akun tersebut perlu dikelola dengan baik dari mulai menentukan hal apa yang akan di posting, message apa yang akan disampaikan, kapan waktu posting, dan lainnya.

Rob Stokes menyatakan agar seorang marketer mendapatkan impact (dampak) yang efektif terhadap penjualan sebuah produk, maka marketer harus menguasai dan memiliki taktik yang baik dalam mengimplementasikan komunikasi pemasaran. Taktik tersebut diantaranya melalui kemampuannya dalam memaksimalkan pengelolaan media sosial. Also known as consumer-generated media, is media (in the form of text, visuals and audio) created to be shared. It has changed the face of marketing by allowing collaboration and connection in a way that no other channel has been able to offer. Stokes (2008:30-31)

Terkait hal tersebut, maka pemanfaatan digitalpreneur oleh pihak kopi oncak dalam proses marketing dapat dikatakan belum optimal. Kopi Oncak harus berkolaborasi secara agresif untuk memposting pesan dalam bentuk gambar, audio, dan visual, serta text yang sesuai dan benar. Bahkan partisipasi konsumen juga dapat diikutsertakan oleh pihak kopi oncak dalam setiap event yang terselenggara. Hal tersebut menjadi hal yang menarik dalam strategi pemasaran Kopi Oncak.

\section{KESIMPULAN}

Strategi pemasaran yang diterapkan oleh manajemen kopi oncak tergolong belum stabil dan optimal. Terlihat dari tahapan STP (Segmentation, Targeting, dan Positioning) pihak kopi oncak. Selain itu, kopi oncak juga telah memanfaatkan media sosial sebagai sarana digitalpreneur yang mereka lakukan namun hal tersebut belum dikelola dengan baik dan optimal. 
Media sosial adalah bagian dari sarana digitalpreneur yang termudah untuk dapat dijalankan pemanfaatannya. Media sosial merupakan 'gerbang' usaha di dunia maya (internet) untuk dapat menjangkau atau 'menjaring' konsumen yang lebih luas dengan cakupan tempat yang sulit dijangkau secara langsung dan riil. Kecepatan penyampaian dan penyebaran informasi merupakan hal yang menjadi keunggulan dari pemanfaatan media sosial. Terkait hal tersebut dapat dinyatakan bahwa media sosial memiliki kekuatan yang "shareable" yang menimbulkan efek feedback dari khalayak dapat dengan segera dianalisis untuk kemajuan market pada usaha yang bersangkutan yaitu Kopi Oncak.

Efek positif yang dijelaskan di atas tentu dapat menjadi stimulan perkembangan usaha dan eksistensi usaha bisnis kopi oncak ini. Biaya relatif murah dan tidak memerlukan keahlian khusus dalam pemanfaatan media sosial atau fasilitas digipreneur lainnya adalah keuntungan dalam hal penggunaan fasilitas tersebut untuk media pemasaran, media sosial dianggap mampu untuk meraih (engage) calon konsumen. Oleh karena itu, tidak heran bahwa usaha kopi oncak justru lebih menitikberatkan pemanfaatan media sosial dibanding dengan pengembangan media digital lain seperti sebuah situs. Meski demikian, ketepatan dalam mengelola juga perlu dipertimbangkan, sehingga pesan dapat tepat sasaran dan sesuai dengan tujuan awal.

\section{DAFTAR PUSTAKA}

Kotler, Philip. 2008. Manajemen Pemasaran Edisi 12 Jilid 2. Jakarta: Indeks Kotler 2008

Moleong, Lexy J. (2007) Metodologi Penelitian Kualitatif, Penerbit PT Remaja Rosdakarya Offset, Bandung (Moleong, 2004:332).

Patrick, Pelsmacker. 2013. Marketing Communication; A European Perspective. Harlow: Pearson. 